Б.А. Телятник, К.А. Здихальський, В.О. Стрельбицький, А.Є. Бородій

Харківський начіональний університет Повітряних Сил ім. І. Кожедуба, Харків

\title{
ОЦІНКА ФАКТОРУ БЕЗПЕКИ ПОВІТРЯНОГО РУХУ, ЯКИЙ ВПЛИВАЄ НА ПРОПУСКНУ ЗДАТНІСТЬ І ОРГАНІЗАЦІЮ ПОЛЬОТІВ
}

В статті розглянуто метод розрахунку пропускної здатності робочого місия диспетчера, процеси управління повітряним рухом та їх кількісні характеристики, тісно пов'язані з характеристиками повітряного середовища, системами відліку координат, принципами поділу повітряного простору, динамічними характеристиками повітряних суден, регламентом, щь визначає правила польотів і управління повітряним рухом, характеристиками операторів в найпростішому контурі управління повітряним рухом і ще багатьма іншими факторами. Разом з тим враховується ефективність функиіонування системи організації повітряного руху, яка характеризується великою кількістю важливих критеріїв, одним з яких являється пропускна здатність самої системи. Метою статті є проведення оџінки фактору безпеки повітряного руху, щцо впливає на пропускну здатність та організацію польотів.

Ключові слова: безпека повітряного руху, безпека польотів, імовірність, кількісні характеристики, система управління повітряним рухом.

\section{Вступ}

Постановка проблеми. Безпека повітряного руху є складним комплексним поняттям, що характеризує певну властивість системи і включає сукупність складових, кожна 3 яких визначає одну 3 іï сторін. Необхідно враховувати той факт, що основною метою введення поняття і кількісної характеристики безпеки польотів є розробка комплексу заходів щодо запобігання авіаційних подій та інцидентів, для вдосконалення процесу забезпечення безпеки польотів на підставі отриманих кількісних даних [1].

Під поняттям безпеки польотів розуміють властивість авіаційно-транспортної системи, що полягає в іiі здатності здійснювати повітряний рух без загрози для життя і здоров'я людей [2]

Безпека польотів - стан авіаційної системи, при якому ризик заподіяння шкоди особам або майну, які перебувають на повітряному судні, не перевищує прийнятного рівня та підтримується на цьому або на більш низькому рівні шляхом безперервного процесу виявлення джерел небезпеки, їх усунення та контролю за факторами ризику.

Забезпечення безпеки польотів - діяльність, що здійснюється відповідними організаціями й авіаційним персоналом та спрямована на виключення випадків завдання шкоди здоров'ю або загрози життю людей, майну фізичних чи юридичних осіб, державному майну. Це ствердження треба розуміти так, що всі повинні усвідомлювати наслідки своїх помилок та прагнути їх уникати. Але одного проголошення цього гасла замало, навіть з урахуванням того, що більшість прагне виконувати свою роботу якісно та безпечно. Тому таке ставлення повинно заохочуватися керівництвом. 3 цією метою необхідно створювати відповідні умови праці, забезпечувати якісну підготовку кадрів, контроль та необхідну матеріально-технічну базу.

Теорія безпеки польотів - це науково обгрунтована методологія забезпечення безпеки польотів.

Для забезпечення безпеки польотів використовується системний підхід, сутність якого полягає у виявленні та врахуванні всіх факторів, зв'язків і відносин, які мають місце в усіх елементах авіаційної системи 3 метою внесення коректив у іiі роботу. Предметом вивчення стають не тільки самі елементи системи, але й їх взаємодія.

Методологія системного підходу передбачає, що розв'язування проблем, які пов'язані з безпекою польотів, залежить від правильної організації системи забезпечення безпеки польотів, котра повинна мати набір засобів технічного та економічного аналізу, а також використовувати наукові досягнення в галузі цільового керування складними системами, а не зводити проблему безпеки тільки до надійності техніки або до аналізу небезпечних ситуацій (авіаційних подій, інцидентів), які вже трапились.

Безпека польотів забезпечується надійним функціонуванням, стійкою взаємодією всіх елементів авіаційної системи, чіткою організацією та високою дисципліною льотної роботи. Вона досягається при повному врахуванні умов виконання польотів, їх організації та забезпеченні.

Безпека польотів в авіаційній системі залежить від якості функціонування усіх іiї елементів та забезпечується:

- високою кваліфікацією і відмінною підготовкою екіпажів повітряних суден;

- льотною придатністю повітряних суден;

- високою якістю забезпечення польотів та управління повітряним рухом. 
Безпека польотів знижується від дії особливих ситуацій, які виникають у результаті таких несприятливих факторів:

- відмови та несправності окремих елементів авіаційної системи;

- вплив несприятливих зовнішніх умов;

- недоліки в різних видах забезпечення польотів;

- помилки авіаційного персоналу та порушення правил експлуатації авіаційної техніки;

- проявлення несприятливих особливостей аеродинаміки та міцності повітряного судна.

Робота із запобігання авіаційних подій та інцидентів не тільки підвищує безпеку польотів, але й економічно вигідна. Витрати на запобігання авіаційних подій завжди будуть виправдані, хоча їх дуже важко порівняти 3 користю, яку отримують внаслідок таких заходів, оскільки не можливо знати, скільки подій вдалося запобігти завдяки заходам для їх запобігання. Однак такі заходи призводять до підвищення надійності авіаційної системи тому, що вони спрямовані на усунення помилок та недоліків у забезпеченні безпеки польотів на всіх рівнях, а також, як правило, призводять до покращення показників роботи авіаційного персоналу і скорочення витрат.

Виходячи з відзначеного, актуальним є питання про складність проблем кількісної оцінки рівня безпеки повітряного руху, необхідністю врахування великої кількості всередині - і позасистемних чинників різної фізичної природи.

На підставі цього необхідно обгрунтувати введені кількісні характеристики повітряного руху і потоків повітряних суден.

Аналіз літератури. В роботі [3] розглянуто метод розрахунку пропускної здатності робочого місця диспетчера.

В роботі [4] розглянуті процеси управління повітряним рухом та їх кількісні характеристики тісно пов'язані 3 характеристиками повітряного середовища, системами відліку координат принципами поділу повітряного простору, динамічними характеристиками повітряних суден, регламентом, що визначає правила польотів і управління повітряним рухом, характеристиками операторів в найпростішому контурі управління повітряним рухом і ще багатьма іншими факторами.

Разом $з$ тим у відомих роботах не враховувалась ефективність функціонування системи організації повітряного руху, яка характеризується великою кількістю важливих критеріїв, одним 3 яких являється пропускна здатність самої системи.

Мета статті. Провести оцінку фактору безпеки повітряного руху, що впливає на пропускну здатність та організацію польотів.

\section{Виклад основного матеріалу}

Безпека польотів є комплексним поняттям, що належить до всієї авіаційно-транспортної системи. Безпекою повітряного руху називають здатність системи функціонувати в заданих умовах таким чином, щоб іiі параметри не вийшли за допустимі (безпечні) значення. Основні параметри системи - координати повітряного судна, його швидкість, запас палива. Обгрунтуванням такого вибору є та обставина, що безпека повітряного руху залежить, наприклад, від значень координат повітряного судна по відношенню до поверхні землі, до координат інших повітряних суден і кордонів небезпечних явищ погоди.

У всіх випадках рівень безпеки польотів за рекомендаціями ICAO повинен бути не нижче значень $1,5 \times 10^{-8}$ (ризик зіткнень повітряних суден) [5].

Кількісною характеристикою ступеня або умовою безпеки повітряного руху можна вважати виконання системи нерівностей:

$$
F_{j}(Y, B) \geq Z_{j}^{*},
$$

де $F_{j}(Y, B)$ - узагальнена функція, що характеризує обмеження по безпеці польотів, введене регламентуючими документами;

$j=I, \mathrm{~m}$ - число таких узагальнених функцій характеристик системи;

$Y=\left(\mathrm{y}_{1}, y_{2, \ldots,} y_{n}\right)-$ вектор стану системи, що включає такі параметри, які визначають безпеку польотів при управлінні повітряним рухом;

$Z_{j}^{*}$ - значення $j$-го виду.

Залежно від цілей розгляду, рівень безпеки польотів як в Україні, так і в ряді інших країн, що входять в ICAO, характеризується комплексом кількісних характеристик.

Найбільш прості абсолютні показники, такі як число інцидентів, авіаційних подій, загиблих пасажирів і членів екіпажів за певний проміжок часу. Більш точними можна вважати показники, наведені до виконаного обсягу транспортних перевезень за певний проміжок часу:

$$
W_{i j}(t)=\frac{w_{i j}(t)}{O_{j}(t)},
$$

де $i$ - індекс виду авіаційної події;

$j$ - індекс типу повітряного судна;

$w_{i j}$ - число авіаційних подій $i$-го виду, що відбулися 3 повітряним судном $j$-го типу за проміжок часу $\mathrm{t}$;

$O_{i}(t)$ - напрацювання або обсяг робіт, виконаний повітряним судном $j$-го типу за проміжок часу $t$.

Для оцінки і аналізу безпеки польотів відповід- 
но до вимог ICAO рекомендується застосовувати такі показники:

- число авіаційних подій (число польотів, в яких вони відбувалися) $w_{a . n}(t)$, де $t_{0} \leq t \leq T-$ певний календарний період часу;

- число загиблих осіб авіаційного персоналу при польотах $K(t)$;

- число авіаційних подій на 100 тисяч посадок (польотів) і на 100 тисяч годин нальоту

$$
\begin{aligned}
& W_{a . n .}^{(n)}(t)=\frac{w_{a . n .}(t)}{N_{n}(t)} \times 10^{-5} ; \\
& W_{\text {n.n. }}^{(\mathrm{t})}(t)=\frac{w_{a . n .}(t)}{T_{\sum}(t)} \times 10^{-5},
\end{aligned}
$$

де $N_{n}(t)$ - загальна кількість посадок за період часу $(t)$

$T_{\Sigma}(t)$ - загальний наліт парку повітряних суден за той же час;

$$
W_{\mathrm{a} . \mathrm{n} .}^{(\mathrm{L})}(t)=\frac{w_{a . n .}(t)}{\mathrm{Z}(t)} \times 10^{-8},
$$

де $W(t)$ - загальна кількість кілометрів нальоту за період $t$;

Для грубої статистичної оцінки частоти виникнення авіаційних подій можна використовувати наступні критерії:

- ймовірність появи авіаційної події в будьякому польоті:

$$
I_{a . n .}(t)=\frac{w_{a . n .}}{N_{n}(t)}
$$
інцидент

- середній наліт на одну подію або серйозний

$$
\begin{aligned}
& K_{a . n .}=\frac{T_{\sum}(t)}{w_{a . n .}(t)} ; \\
& T_{\sum}(t)=\sum_{i-1}^{n} t_{a . n .}^{(i)},
\end{aligned}
$$

де $w_{a . n}$ - число повітряних суден розглянутого типу;

$$
t_{a . n .}^{(i)} \text { - наліт } i \text {-го повітряного судна до авіацій- }
$$
ної події.
Для оцінки стану безпеки польотів підсистеми “особа управління повітряним рухом - екіпаж - повітряне судно” може бути використаний такий показник як:

$$
I_{i}(t)=1-\lim _{t \rightarrow \infty} \times \frac{w_{i}(t)}{N(t)},
$$

де $w_{i}$ - число польотів $i$-ою подією,

$i$ - індекс, що визначає подія, що характеризує кінцевий результат польоту, типу катастрофи (к), аварії $(a)$, авіаційної події $(n)$, серйозного інциденту (ci), ускладнення $(y)$;

$N(t)$ - загальна кількість польотів за час $t$.

При значній частці польотів поза маршрутами обслуговування повітряного руху в певній зоні управління безпека повітряного руху характеризується ймовірністю зіткнень або небезпечних зближень. Якщо число зіткнень (небезпечних зближень) повітряних суден позначити через $W$, то може бути використаний показник виду

$$
W=w(t) \times B^{2},
$$

де $w(t)$ - коефіцієнт пропорційності, що враховує параметри системи;

$B$ - параметр, що характеризує інтенсивність pyxy.

\section{Висновки}

Кожна 3 наведених кількісних характеристик безпеки повітряного руху використовується в певних умовах. Складність проблем кількісної оцінки рівня безпеки повітряних суден багато в чому залежить необхідністю врахування великої кількості системних та позасистемних чинників різної фізичної природи, наприклад, таких, як інтенсивність i характер потоків, метеорологічні умови, укомплектованість диспетчерських змін, умови роботи диспетчерів, тощо.

Введені кількісні характеристики повітряного руху і потоків повітряних суден відносяться до основних і не охоплюють всього. Інші, подібні кількісним характеристикам, зазвичай вводять і використовують в кожному конкретному випадку досліджуваного процесу в системі управління повітряним рухом.

\section{Список літератури}

1. Закон України “Про Державну програму авіаційної безпеки цивільної авіації № 1965-VIII від 21.03.2017 р.” [Електронний ресурс]. - Режим доступу: http://zakon.rada.gov.ua/laws/show/1965-19.

2. Постанова Кабінету Міністрів України “Про утворення Міжвідомчої комісії з авіаційної безпеки цивільної авіації № 938 від 10.10.2012 р.” [Електронний ресурс]. - Режим доступу: https://zakon.rada.gov.ua/laws/show/938-2012$\% \mathrm{D} 0 \% \mathrm{BF}$.

3. Постанова Кабінету Міністрів України “Про затвердження Положення про Державну авіаційну службу України № 520 від 08.10.2014 р.” [Електронний ресурс].- Режим доступу: https://zakon.rada.gov.ua/laws/show/520-2014$\% \mathrm{D} 0 \% \mathrm{BF}$.

4. Наказ Міністерства транспорту та зв'язку України “Про затвердження Положення про розслідування авіаційних подій та інцидентів № 159 від 26.03.2010 р.” [Електронний ресурс]. - Режим доступу: https://zakon.rada.gov.ua/ laws/show/z0590-10. 
5. Наказ Міністерства транспорту та зв'язку України “Про затвердження Правил сертифікації експлуатантів, що здійснюють експлуатацію цивільних повітряних суден (літаків) з метою виконання комерційних транспортних перевезень згідно з вимогами OPS 1 № 430 від 05.07.2010 р.” [Електронний ресурс]. - Режим доступу: https://zakon.rada.gov.ua/ laws/show/z0558-10.

6. Наказ Міністерства транспорту та зв'язку України “Про затвердження Правил проведення службового розслідування актів незаконного втручання в діяльність цивільної авіації № 804 від 02.11.2010 р.” [Електронний ресурс]. Режим доступу: https://zakon.rada.gov.ua/laws/show/z0106-11.

7. Офіціальний сайт AVIA.GOV. Політика Європейської конференції цивільної авіації в сфері авіаційної безпеки. - Режим доступу: https://avia.gov.ua/bezpeka-aviatsiyi/aviatsijna-bezpeka/perelik-normatyvno-pravovyh-dokumentiv-zaviatsijnoyi-bezpeky/.

8. Наказ Державної авіаційної служби України “Про затвердження Авіаційних правил України. Правила охорони повітряних суден та інших важливих об’єктів цивільної авіації, забезпечення контролю доступу до них № 1017 від 07. 08. 2019 p" [Електронний ресурс]. - Режим доступу: https://zakon.rada.gov.ua/laws/show/z0991-19.

9. Офіціальний сайт UN.ORG. Резолюція 2309. Ради Безпеки ООН, 7775 засідання від 22.09.2016 року. - Режим доступу: https://un.org/sc/ctc/wp-content/uploads/2017/01/N1629581.

10. Офіціальний сайт AVIA.GOV. Керівництво з авіаційної безпеки (Документ 8973 ICAO, 11-те видання, 2019 року). Довідкове керівництво з проведення перевірок з питань забезпечення авіаційної безпеки (ICAO, Doc 9807, видання друге, 2016 року). - Режим доступу: https:/avia.gov.ua/bezpeka-aviatsiyi/aviatsijna-bezpeka/perelik-normatyvno-pravovyhdokumentiv-z-aviatsijnoyi-bezpeky/.

11. Офіціальний сайт AVIA.GOV. Регламент Свропейської Комісії (EU) 2015/1998 від 5 листопада 2015 року про встановлення детальних заходів з імплементації загальних основних стандартів авіаційної безпеки. - Режим доступу: https://avia.gov.ua/bezpeka-aviatsiyi/aviatsijna-bezpeka/perelik-normatyvno-pravovyh-dokumentiv-z-aviatsijnoyi-bezpeky/.

12. Наказ Міністерства оборони України "Правила розслідування авіаційних подій та інцидентів в авіації Збройних Сил України № 256 від 19.05.2010 p.” [Електронний ресурс]. - Режим доступу: http:// zakon.rada.gov.ua/ laws/show/z0386-10.

13. Наказ Державної авіаційної служби України, Міністерства оборони України “Авіаційні правила України. Правила використання повітряного простору України № 430/210 від 11.05. 2018 р.” [Електронний ресурс]. - Режим доступу: https://zakon.rada.gov.ua/laws/show/z1056-18.

14. Наказ Міністерства транспорту України, Міністерства оборони України "Інструкція про розслідування порушень порядку використання повітряного простору № 50/18 від 27.01.2003 р.” [Електронний ресурс]. - Режим доступу: https://zakon.rada.gov.ua/laws/show/z0116-03.

15. Наказ Командувача Повітряних Сил Збройних Сил України “Положення про запобігання авіаційних подій в авіації Повітряних Сил Збройних Сил України № 444 від 17.12.2011р.” [Електронний ресурс]. - Режим доступу: https:/www.mil.gov.ua/ministry/sklad-zbrojnix-sil-ukraini/povitryani-sili/.

\section{Відомості про авторів:}

\section{Телятник Борис Анатолійович}

викладач

Харківського національного

університету Повітряних Сил ім. І. Кожедуба,

Харків, Україна

https://orcid.org/0000-0002-5239-4190

\section{Здихальський Костянтин Андрійович}

магістрант

Харківського національного університету

Повітряних Сил ім. І. Кожедуба,

Харків, Україна

https://orcid.org/0000-0002-2250-2189

\section{Стрельбицький Віталій Олександрович} магістрант

Харківського національного університету

Повітряних Сил ім. І. Кожедуба,

Харків, Україна

https://orcid.org/0000-0003-3815-0103

\section{Information about the authors:}

\section{Boris Telyatnik}

Instructor

of Ivan Kozhedub Kharkiv

National Air Force University,

Kharkiv, Ukraine

https://orcid.org/0000-0002-5239-4190

\section{Kostiantyn Zdykhalskyi}

Postgraduate Student

of Ivan Kozhedub Kharkiv

National Air Force University,

Kharkiv, Ukraine

https://orcid.org/0000-0002-2250-2189

\author{
Vitalii Strelbytskyi \\ Postgraduate Student \\ of Ivan Kozhedub Kharkiv \\ National Air Force University, \\ Kharkiv, Ukraine \\ https://orcid.org/0000-0003-3815-0103
}


Бородій Андрій Свгенійович

курсант

Харківського національного університету

Повітряних Сил ім. І. Кожедуба,

Харків, Україна

https://orcid.org/0000-0002-8884-0412

\author{
Andrii Borodii \\ Cadet \\ of Ivan Kozhedub Kharkiv \\ National Air Force University, \\ Kharkiv, Ukraine \\ https://orcid.org/0000-0002-8884-0412
}

\title{
ОЦЕНКА ФАКТОРА БЕЗОПАСНОСТИ ВОЗДУШНОГО ДВИЖЕНИЯ, ВЛИЯЮЩЕГО НА ПРОПУСКНУЮ СПОСОБНОСТЬ И ОРГАНИЗАЦИЮ ПОЛЕТОВ
}

\author{
Б.А. Телятник, К.А. Здыхальский, В.А. Стрельбицкий, А.Е. Бородий
}

В статье рассмотрен метод расчета пропускной способности рабочего места диспетчера, прочессы управления воздушным движением и их количественные характеристики, тесно связанные с характеристиками воздушной среды, системами отсчета координат, принципами распределения воздушного пространства, динамическими характеристиками воздушных судов, регламентом, который определяет правила полетов и управления воздушным движением, характеристиками операторов в самом простом контуре управления воздушным движением и еще многими другими факторами. Вместе с тем учитывается эффективность функиионирования системы организации воздушного движения, которая характеризуется большим количеством важных критериев, одним из которых является пропускная способность самой системы. Целью статьи является проведение оценки фактора безопасности воздушного движения, которое влияет на пропускную способность и организацию полетов. Безопасность полетов есть комплексное понятие, которое принадлежит ко всей авиационно-транспортной системе. Безопасностью воздушного движения называют способность системы функиионировать в заданных условиях таким образом, чтобы ее параметры не вышли за допустимые (безопасные) значения. Основные параметры системы - координаты воздушного судна, его скорость, запас топлива. Обоснованием такого выбора является то обстоятельство, что безопасность воздушного движения зависит, например, от значений координат воздушного судна по отночению к поверхности земли, к координатам других воздушных судов и грании опасных явлений погоды. Во всех случаях уровень безопасности полетов за рекомендациями ІСАО должен быть не ниже значений $1,5 \times 10^{-8}$ (риск столкновений воздушных судов). В зависимости от иелей рассмотрения, уровень безопасности полетов, как в Украине, так и в ряде других стран, которые входят в ІСАО, характеризуется комплексом количественных характеристик. Наиболее простые абсолютные показатели, такие как число инцидентов, авиационных происшествий, погибших пассажиров и членов экипажей за определенный промежуток времени.

Ключевые слова: безопасность воздушного движения, безопасность полетов, вероятность, количественные характеристики, система управления воздушным движением.

\section{EVALUATION OF AIR TRAFFIC SAFETY FACTOR AFFECTING FLOW CAPACITY AND ORGANIZATION}

\section{B. Telyatnik, K. Zdyhalsky, V. Strelbytsky, A. Borodiy}

The paper considers the method of calculating the capacity of the workplace of the dispatcher, the processes of air traffic management and their quantitative characteristics are closely related to the characteristics of the air environment, reference frames, principles of separation of air space, dynamic characteristics of aircraft, regulations that determine the rules of flight and management air traffic, operator characteristics in the simplest air traffic control circuit, and many other factors. However, the efficiency of the operation of the air traffic management system, which is characterized by a large number of important criteria, is one of which is the capacity of the system itself. The purpose of the article is to evaluate the factor of air traffic safety that affects the capacity and organization of flights. Flight safety is a complex concept that applies to the entire aviation system. Air traffic safety refers to the ability of a system to function under specified conditions in such a way that its parameters do not go beyond acceptable (safe) values. The main parameters of the system - the coordinates of the aircraft, its speed, fuel supply. The justification for this choice is the fact that the safety of air traffic depends, for example, on the values of the coordinates of the aircraft relative to the surface of the earth, to the coordinates of other aircraft and the borders of hazardous weather events. In all cases, the safety level of ICAO recommendations should not be lower than $1,5 \times 10^{-8}$ (risk of collision of the aircraft). Depending on the purpose of the review, the level of flight safety in both Ukraine and several other ICAO countries is characterized by a set of quantitative characteristics. The simplest absolute figures, such as the number of incidents, aviation events, lost passengers and crew over a period of time.

Keywords: air traffic safety, flight safety, probability, quantitative characteristics, air traffic management system. 